\title{
SUPPORT VECTOR MACHINES UNTUK MENYELESAIKAN MASALAH KLASIFIKASI PADA PENGENALAN POLA
}

\author{
Abdul Azis Abdillah \\ Jurusan Teknik Mesin, Politeknik Negeri Jakarta \\ e-mail :abdul.abdillah@mesin.pnj.ac.id
}

\begin{abstract}
Support Vector Machines (SVM) are known as the latest machine learning (machine learning) methods to solve classification problems in pattern recognition. This paper discusses the use of SVM in solving problems in pattern recognition. An example of the problem given in this paper contains a collection of data on Any Linearly Separable Datase, Any dataset with Noise, and Real datasets.
\end{abstract}

Key words: machine learning, pattern recognition, SVM

\begin{abstract}
ABSTRAK
Support Vector Machines (SVM) dikenal sebagai metode machine learning (pembelajaran mesin) paling mutakhir untuk menyelesaikan masalah klasifikasi pada pengenalan pola. Tulisan ini bertujuan untuk membahas penggunaan SVM dalam memecahkan masalah klasifikasi pada pengenalan pola. Contoh masalah yang diberikan pada tulisan ini meliputi klasifikasi data pada Sembarang Linearly Separable Dataset, Sembarang Dataset dengan Noise, dan Real dataset.
\end{abstract}

Kata kunci : klasifikasi, pengenalan pola, SVM

\section{PENDAHULUAN}

Suport Vector Machines (SVM) merupakan salah satu metode machine learning (pembelajaran mesin) untuk menyelesaikan masalah klasifikasi. SVM diperkenalkan oleh Boser, Guyon dan Vapnik, pada tahun 1992 di konferensi tahunan Computational Learning Theory. Konsep dasar SVM adalah mencari suatu hyperplane yang dapat memisahkan dua buah kelas dengan margin maksimum. Secara teori, pemilihan margin maksimum ini akan memberikan kemampuan generalisasi yang paling baik. Sedangkan secara intuitif, jika marginnya maksimum maka ketika hyperplane optimalnya dicoba pada data selain data pembelajaran, namun dengan kasus yang sama maka hyperplane optimal tersebut tetap dapat mengklasifikasi data ke dalam dua kelas dengan baik.

Prinsip dasar SVM adalah klasifikasi biner, dan selanjutnya dikembangkan agar dapat bekerja pada kasus multiclass. SVM telah banyak digunakan untuk menyelesaikan masalah klasifikasi pada pengenalan pola. Sebagai contoh, SVM telah berhasil menyelesaikan masalah klasifikasi dalam beberapa bidang seperti Face Recognition (pengenalan wajah) [1], Handwritten Recognition (pengenalan tulisan) [2], Iris Recognition (pengenalan retina mata) [3], Information Retrieval (penarikan informasi) [4], Medical Field (bidang Medis) [5] dan masih banyak yang lain.

Tulisan ini bertujuan untuk membahas penggunaan metode SVM dalam menyelesaikan masalah klasifikasi pada pengenalan pola.

\section{LANDASAN TEORI}

Pada bagian ini akan dijelaskan tentang metode Support Vector Machines (SVM) pada data yang Linearly Separable. 


\section{Hard Margin Support Vector Machines}

Misalkan S merupakan data pelatihan yang Linearly Separable, dimana $S=$ $\left\{\left(x_{i}, t_{i}\right)\right\}_{=1, \ldots, \mathrm{m}}$ merupakan suatu himpunan dengan $\mathrm{m}$ buah data, dengan $x_{i} \in R^{n}$ dan $t_{i}=\{1,-1\}$. Masalah klasifikasi biner (klasifikasi dua kelas) dikatakan sebagai Linearly Separable jika terdapat paling sedikit sebuah hyperplane yang dapat memisahkan setiap data di S ke dalam dua kelas. Permasalahan ini dikenal dengan sebutan Hard Margin Support Vector Machines.

Persamaan $\quad w^{T} x+b=0 \quad$ disebut hyperplane. Jika suatu data memiliki label $t_{i}=1$, maka data tersebut dimasukkan ke dalam kelas $A_{+}$(kelas positif). Sedangkan jika suatu data memiliki label $t_{i}=-1$, maka data tersebut dimasukkan ke dalam kelas $A_{-}$ (kelas negatif). Fungsi linier yang digunakan sebagai fungsi keputusan pada SVM adalah $f(x)=w^{T} x+b$, dimana $\mathrm{x}$ adalah vektor input yang berupa data, w adalah vektor bobot, dan $\mathrm{b}$ adalah suatu bias.

Fungsi keputusan ini digunakan untuk memisahkan dua buah kelas, sehingga untuk setiap data $x_{i}, \quad i=1,2, \ldots, m$ dimana $t_{i}=1$ (kelas $A_{+}$) akan membuat $w^{T} x+b>0$ dan untuk setiap data $x_{i}$, $i=1,2, \ldots, m$ dimana $t_{i}=-1$ (kelas $\left.A_{-}\right)$akan membuat $w^{T} x+b<0$, sehingga untuk setiap data $x^{i}$ akan diklasifikasi dengan benar jika $t_{i}\left(w^{T} x_{i}+b\right)>0$. Karena fungsi keputusan $f(x)=w^{T} x+b$ tergantung pada parameter $\mathrm{w}$ dan $\mathrm{b}$, maka harus dicari nilai parameter $w$ dan $b$ yang dapat memaksimumkan margin.

Solusinya yaitu dengan menggunakan bentuk canonical dari hyperplane, yaitu $t_{i}\left(w^{T} x_{i}+b\right)=1$, dimana $t_{i}=1,-1$, $i=1,2, \ldots, m$ dimana bentuk canonical paralel terhadap hyperplane dan memiliki jarak yang sama terhadap hyperplane. Bentuk canonical dari hyperplane pada kelas $A_{+}$yaitu $\left(w^{T} x_{i}^{+}+b\right)=1, \quad i=1,2, \ldots, m$ sedangkan pada kelas A- yaitu $\left(w^{T} x_{i}^{-}+\right.$ $b)=-1, i=1,2, \ldots, m \quad$ Selanjutnya semua data pembelajaran akan memenuhi kondisi berikut: $t_{i}\left(w^{T} x_{i}+\right.$ b) $\geq 1$.

Pada SVM, hyperplane optimal diperoleh saat margin antara dua kelas tersebut maksimum. Misalkan $d_{+}$adalah jarak dari data $x_{i}^{+}$ke hyperplane dan $d_{-}$ adalah jarak dari data $x_{i}^{-}$ke hyperplane, maka margin pada SVM didefinisikan sebagai $d=d_{+}+d_{-}=\frac{2}{|w|}, \quad$ dimana $d_{+}=d_{-}$.

Berdasarkan hal ini, maka masalah memaksimalkan margin $\frac{2}{|w|}$, ekuivalen dengan meminimumkan $\frac{1}{2}|w|^{2}$. Sehingga model matematis dari masalah Hard Margin Support Vector Machines dapat dinyatakan sebagai berikut [6-8]:

$\min _{\mathrm{w}, \mathrm{b}} \frac{1}{2}\|w\|^{2}$

Dengan kendala :

$t_{i}\left(w^{T} x_{i}+b\right) \geq 1, i=1,2, \ldots, m$

Solusi dari masalah optimasi ini adalah diperolehnya nilai $a_{i}$ yang nantinya digunakan untuk menentukan nilai w dan b dengan rumus [6-8]: $w=\sum_{i=1}^{m} a_{i} t_{i} x_{i}$ dan $b=t_{i}-w^{T} x_{i}$.

Terdapat nilai $a_{i}$ untuk setiap data pelatihan. Data pelatihan yang memiliki nilai $a_{i}>0$ disebut sebagai support vector. Dengan demikian fungsi keputusan yang dihasilkan hanya dipengaruhi oleh support vector. Setelah solusi permasalahan pemrograman kuadrat ditemukan (nilai $a_{i}$ ) maka kelas dari data pengujian $\mathrm{x}$ dapat ditentukan 
berdasarkan nilai dari fungsi keputusan: $f(x)=\sum_{i=1}^{n s} a_{i} t_{i} x_{i}^{T} x+b$.

\section{Soft Margin Support Vector Machines}

Pada umumnya dua buah kelas pada input space tidak dapat terpisah secara sempurna. Hal ini menyebabkan kendala $t_{i}\left(w^{T} x_{i}+b\right) \geq 1, \quad i=1,2, \ldots, m$ tidak dapat terpenuhi, sehingga optimasi tidak dapat dilakukan. Namun, kita tentu ingin mengontrol data yang berada pada kelas yang tidak sesuai. Selanjutnya, untuk mengontrol data yang berada pada kelas yang tidak sesuai kita menggunakan slack variable: $\xi_{i} \geq 0, i=1,2, \ldots, m$.

Dengan demikian, masalah optimisasi pada klasifikasi dengan melibatkan slack variable dapat dinyatakan sebagai [6-8]:

$\min _{\mathrm{w}, \mathrm{b}} \frac{1}{2}\|w\|^{2}+C \sum_{i=1}^{m} \xi_{i}$

Dengan kendala :

$t_{i}\left(w^{T} x_{i}+b\right) \geq 1-\xi_{i}, i=1,2, \ldots, m$

$\xi_{i} \geq 0, i=1,2, \ldots, m$

Permasalahan ini dikenal dengan sebutan Soft Margin Support Vector Machines, dimana C $>0$ adalah parameter yang menentukan besarnya penalti akibat kesalahan dalam klasifikasi data dan nilainya di tentukan oleh user. Parameter $\mathrm{C}$ ditentukan dengan mencoba beberapa nilai dan dievaluasi efeknya terhadap akurasi yang dicapai oleh SVM. Solusi dari masalah soft margin SVM hampir identik dengan hard margin SVM. Sedikit perbedaan antara keduanya adalah pada kendala dual problem, dimana terdapat penambahan kendala $0 \leq a_{i} \leq C$ pada soft margin SVM.

\section{HASIL DAN PEMBAHASAN}

Pada bagian ini akan diberikan contoh masalah dan penyelesaian menggunakan SVM dengan data input yang berasal dari Sembarang Linearly Separable Dataset, Sembarang Dataset dengan Noise, dan Real dataset. Penulis melakukan percobaan menggunakan software LIBSVM [9].

Untuk mengevaluasi kinerja dari SVM pada penelitian ini, penulis menggunakan satuan Accuracy (Akurasi) [10]. Akurasi dalam klasifikasi adalah persentase ketepatan record data yang diklasifikasikan secara benar. Formula Akurasi adalah sebagai berikut [10] :

$$
\text { Akurasi }=\frac{T P+T N}{T P+F P+F N+T N}
$$

Dimana, TP adalah jumlah record positif yang diklasifikasikan sebagai positif, FP adalah jumlah record negatif yang diklasifikasikan sebagai positif, FN adalah jumlah record positif yang diklasifikasikan sebagai negatif, TN adalah jumlah record negatif yang diklasifikasikan sebagai negatif.

\section{Sembarang Linear Separable Dataset}

Sembarang Linear Separable Dataset yang digunakan pada contoh ini adalah Logika AND. Pada logika AND terdapat dua nilai yaitu true dan false. Logika AND memberikan jawaban true jika kedua nilai input adalah true, selain itu jawabannya adalah false. Jika true dimisalkan dengan nilai 1 dan false dimisalkan dengan nilai -1, maka akan diperoleh empat data input beserta target. Data input beserta target yang di dapat berdasarkan logika AND yaitu $\boldsymbol{x}=$ $\{(1,1) ;(1,-1) ;(-1,1) ;(-1,-1)\}$ dengan target $t=\{1 ;-1 ;-1 ;-1\}$.

Selanjutnya digunakan metode SVM untuk mengklasifikasikan data input 
dengan mengujikan beberapa nilai $\mathrm{C}$. hasil percobaan ini diperlihatkan pada Tabel I (a). Berdasarkan nilai parameter yang telah di uji coba pada Tabel I (a) diperoleh nilai parameter $\mathrm{C}$ yang optimal berkisar antara $\mathrm{C}=1$ sampai $\infty$. Optimal dalam arti akurasi yang diperoleh dari hasil klasifikasi dataset adalah yang tertinggi yaitu mencapai $100 \%$.

Dari percobaan pada logika AND terlihat semakin besar nilai C yang digunakan, maka akan semakin besar akurasi yang dihasilkan. Selanjutnya pilih nilai parameter yang menghasilkan akurasi terbaik, pada kasus data dengan logika AND dapat digunakan nilai $C$ antara 1 sampai $\infty$. Pada kasus ini penulis menggunakan nilai $C=1$. Selanjutnya nilai a yang digunakan untuk setiap data input $\mathrm{x}$ dengan target $\mathrm{t}$ diperoleh dari yang bersesuaian dengan nilai parameter $\mathrm{C}=1$ yaitu $a=\{1 ; 0.5 ; 0.5 ; 0\}$.

Dengan didapatkannya nilai a untuk setiap data input $x$ dengan target $t$, maka diperoleh nilai $\mathrm{w}=(1,1), \mathrm{b}=-1$. Sehingga fungsi keputusan yang diperoleh adalah $f(x)=x_{1}+x_{2}-1$ atau hyperplane adalah $x_{1}+x_{2}-1=0$.

\section{Sembarang Dataset dengan Noise}

Pada bagian ini akan dijelaskan bagaimana cara memisahkan dataset yang memiliki noise. Berikut merupakan contoh dataset yang memiliki sebuah noise $x=$ $\{(1,1) ;(2,1) ;(1,2) ;(-2,-2) ;(-1,-1)$; $(-1,-2) ;(-2,-1)\}$ dengan target $t=$ $\{1 ; 1 ; 1 ; 1 ;-1 ;-1 ;-1\}$.

Hasil percobaan menggunakan Sembarang Dataset dengan Noise dapat dilihat pada tabel I (b). Sejalan dengan logika AND, pada Sembarang Dataset dengan Noise semakin besar nilai C yang digunakan, maka akan semakin besar akurasi yang dihasilkan. Nilai akurasi optimal pada dataset berkisar antara
$\mathrm{C}=0.1$ sampai $\infty$ Perbedaan dengan contoh sebelumnya yaitu terdapat sebuah misklasifikasi data, sehingga mengakibatkan akurasi optimal dari dataset hanya mencapai $85.71 \%$.

\section{Real Dataset}

Real Dataset yang digunakan pada tulisan ini adalah Dataset Pima Indians Diabetes [11-12]. Dataset Pima merupakan dataset yang umum digunakan pada penelitian terkait pendeteksian penyakit diabetes. Dataset PIMA terdiri dari 768 data pasien yang semuanya adalah perempuan dengan usia $\geq 21$ tahun. Dataset berisi 500 pasien tidak terdeteksi diabetes dan 268 pasien terdeteksi diabetes. Selain itu, dataset PIMA terdiri dari dua kelas yaitu kelas positif dan kelas negatif serta delapan atribut dari penyakit diabetes yaitu

1. Jumlah kali hamil

2. Konsentrasi glukosa plasma 2 jam dalam tes toleransi glukosa oral

3. Tekanan darah diastolik (mm $\mathrm{Hg}$ )

4. Triceps ketebalan lipatan kulit (mm)

5. Serum insulin 2-Jam (mu U / ml)

6. Indeks massa tubuh $(\mathrm{kg} / \mathrm{m} 2)$

7. Riwayat Keturunan Penyakit Diabetes

8. Umur (tahun)

Hasil percobaan menggunakan dataset Pima dapat dilihat pada tabel I (c). Pada dataset Pima nilai parameter $C$ yang menghasilkan akurasi tertinggi diperoleh saat nilainya 10 . Nilai akurasi yang diperoleh hanya mencapai $78.13 \%$. Berbeda dengan dua contoh sebelumnya, yang dimana semakin besar nilai $C$ yang digunakan maka akurasi yang diperoleh semakin besar.

\section{KESIMPULAN}

Pada penelitian ini telah dibahas SVM dalam menyelesaikan masalah 
klasifikasi pada pengenalan pola. Selain itu, telah dilakukan simulasi program menggunakan data yang berasal dari Sembarang Linear Separable Dataset, Sembarang Dataset dengan Noise, dan Real dataset. Berdasarkan hasil simulasi, SVM dapat mengklasifikasikan datadata dengan tepat, dimana pemilihan nilai parameter $\mathrm{C}$ memegang peranan yang sangat penting dalam menentukan nilai akurasi yang paling optimal.

\section{DAFTAR PUSTAKA}

[1] Khan, N. 2012. A novel SVM+NDA model for classification with an application to face recognition. Pattern Recognition 45, pp 66-79.

[2] Adankon M. M., dkk, 2009. Application to hand writing recognition. Pattern Recognition 42, 3264, new Frontiers in Handwriting Recognition.

[3] Rai, H. dkk, 2014. Iris Recognition using Combined Support Vector Machine and Hamming distance approach. Expert Systems with Applications 41, pp 588-593.

[4] Abdillah, A. A., dkk, 2015. Uji Kinerja Learning to Rank dengan Metode Support Vector Regression. IndoMS Journal on Industrial and Applied Mathematics 2, 15.

[5] Purnami, S. W. 2009. A new smooth support vector machines and its applications in diabetes disease diagnosis. Journal of Computer Science 5, pp 1003-1008.
[6] Bishop, C. M., 2006. Pattern Recognition and Machine Learning (Information Science and Statistics) (Springer-VerlagNew York, Inc., Secaucus, NJ, USA).

[7] B. Scholkopf, dkk, 2001. Learning with Kernels: Support Vector Machines, Regularization, Optimization, and Beyond (MIT Press, Cambridge, MA, USA).

[8] Cristianini N. dkk, 2000. An Introduction to Support Vector Machines: And Other Kernel-based Learning Methods (Cambridge University Press, New York, NY, USA).

[9] Chang C.-C. dkk, 2011. Libsvm: A library for support vector machines. ACM Transactions on Intelligent Systems and Technology 2, 27:1 (2011), software available at http://www.csie.ntu.edu.tw/ $\sim$ cjlin/libsvm.

[10] Gorunescu, F. 2011. Data mining concepts, models and techniques (Springer).

[11] M. Lichman, \UCI machine learning repository," http://archive.ics.uci.edu/ml (2013).

[12] J. W. Smith, 1988. Using the ADAP learning algorithm to forecast the onset of diabetes mellitus. in Proceedings of the Annual Symposium on Computer Application in Medical Care American Medical Informatics Association) pp. 261-265. 
Tabel 1. Hasil akurasi berdasarkan variasi nilai C yang digunakan pada (a) Logika AND, (b) dataset yang memiliki noise, dan (c) dataset pima

\begin{tabular}{|c|c|c|c|}
\hline Nilai C & (a) & (b) & (c) \\
\hline 0.001 & 75 & $57.14 \%$ & $77.08 \%$ \\
\hline 0.01 & 75 & $57.14 \%$ & $77.34 \%$ \\
\hline 0.1 & 75 & $85.71 \%$ & $77.34 \%$ \\
\hline 1 & 100 & $85.71 \%$ & $77.34 \%$ \\
\hline 10 & 100 & $85.71 \%$ & $78.13 \%$ \\
\hline 100 & 100 & $85.71 \%$ & $76.30 \%$ \\
\hline 1000 & 100 & $85.71 \%$ & $74.48 \%$ \\
\hline 10000 & 100 & $85.71 \%$ & $73.70 \%$ \\
\hline
\end{tabular}

